\title{
La estructura de vidrios de alumino-silicato y de granito para la fabricación de materiales de construcción vitrocerámicos de tipo petrúrgico
}

\author{
Structure of aluminosilicate melts produced from granite rocks \\ for the manufacturing of petrurgical glass-ceramics \\ construction materials
}

\author{
A. G. SIMAKIN *, T.P.SALOVA *,M. ROMERO **, J. Ma. RINCÓN ** \\ (")IEM RAS Chernogolovka, Rusia \\ (") Instituto de Ciencias de la Construcción Eduardo Torroja-CSIC, España
}

Fecha de recepción: 7-VII-00

\section{RESUMEN}

Los fundidos de alumino-silicato son una fase parcialmente ordenada. Su estructura puede ser descrita en términos de la coordinación de tetraedros de alúmina-silice también denominados especies $Q$. La proporción de tetraedros con diferente grado de conectividad entre si se ha investigado por espectroscopías de RMN e IR en fundidos de silicatos alcalinos, fundamentalmente de sodio. Así, la estructura de medio alcance puede caracterizarse por el tamaño de los anillos compuestos de tetraedros de alúmina-silice. La distribución de tamaño se puede deducir por IR observándose un aumento sistemático de la secuencia en el binario Albita-Anortita. Se ha observado además la destrucción parcial de la estructura por la disolución de agua que sustituye a los grupos de cuatro anillos por anillos de seis grupos. Los cambios bruscos en viscosidad y difusividad se detectan cuando aumenta el contenido de oxígenos no-puente. De la misma manera, se presentan y discuten los resultados en vidrios de sílicato de litio con diferentes contenidos en moléculas de agua en el fundido original. La presencia de agua en la red de vidrios susceptibles de ser convertidos en materiales vitrocerámicos $y$ petrúrgicos como materiales de construcción tiene repercusión en los procesos de nucleación y crecimiento cristalino que son necesarios para la fabricación de este tipo de materiales. Se discute, pues, el efecto de este contenido en agua sobre las velocidades de nucleación y cristalización de manera que al rebajarse la viscosidad se incrementan los valores de tipo cinético en estos procesos.

\begin{abstract}
SUMMARY
The aluminosilicate melt is a partly ordered phase and is the origin of glass for producing glassceramics and petrurgical materials. They are well extended used as consiruction materials for pavings and coatings. Its structure can be described in the terms of the alumino-silica tetrahedras coordination so-called $Q$ speciation. The proportions of tetrahedra with different degree of connectivity with others (from totally connected to free)has been studied by NMR and IR methods for sodium-silicate melts. Medium range structure can be characterized by the sizes of irreducible rings composed of the alumino-silica tetrahedra. Systematic increase of the four member rings proportion in the sequence of the Ab-An glasses were observed. The water dissolution in sodium-silicate glass affects the $Q$ speciation. Cations network-modifiers positions in the melt structure are important to know since these cations stabilize particular structure configurations. Modification of the distribution of $\mathrm{Na}$ coordination in the sodium-silicate glass at water dissolution was determined by NMR spectroscopy. The observed modification of the hydrous aluminosilicate melt structure resulted in the shift of the eutectic composition in the granite system with decreasing of the crystallization field of feldspars. The feldspar growth rates show practically no dependence on the water content in the concentration range 2-4 wt.\%. Likewise, the solved water has a little influence on the crystal growth rate of the lithium silicate phase in lithium containing glasses in accordance with estimated enhancing of the diffusion transport.
\end{abstract}




\section{INTRODUCCIÓN}

Todas las propiedades de los vidrios y fundidos de silicato que son el punto de partida para la obtención de materiales vitrocerámicos y de tipo petrúrgico que se obtienen por ciclos térmicos controlados de nucleación y crecimiento cristalino dependen de la estructura interna del fundido y vidrio original. Así, en los fundidos de tipo aluminio-silicato la unidad estructural básica son los tetraedros que son el esqueleto básico en su red enlazados por oxígenos puente y en la que quedan oxígenos no-puente sin enlazar entre sí. La red de este tipo de fundidos es, pues, una red interconectada de tetraedros de sílice de tipo polimérico. El grado de polimerización afecta a las propiedades de transporte tal como la viscosidad y la difusividad afectando, a su vez, al crecimiento de las fases sólidas o fases cristalinas precipitadas en la red vítrea por ciclos térmicos de nucleación y cristalización. El orden del fundido y del vidrio original es parcial, siendo muy dificil de describir y caracterizar instrumentalmente. La contribución del orden de corto alcance y del de largo alcance se puede, no obstante, inferir por estudios de la cinética de cristalización comparados y con los datos de diagramas de equilibrio entre fases que aportan datos sobre las transiciones de la estructura. Este tipo de investigaciones son muy útiles para controlar bien los procesos de obtención de vitrocerámicos que tienen aplicación como materiales de construcción en arquitectura como pavimentos y revestimientos (1) (2).

\section{ORDEN DE CORTO ALCANCE EN FUNDIDOS DE SILICATO}

\subsection{Especies tipo $Q$}

La manera normal para moderar las tensiones en la estructura reticular de fundidos de silicato es un ordenamiento basado en tetraedros de silicio coordinados con cuatro oxígenos y compartidos por medio de oxígenos puente con tetraedros de alumnio y oxígeno. Estos tetraedros se pueden aislar como en la estructura del olivino o compartiendo oxígenos en cada vértice. Así, se pueden distinguir los tipos diferentes de red formando grupos de posiciones estructurales de átomos según el número de oxígenos compartidos. Ésta es la llamada clasificación o tipología $Q$ (3). Se pueden encontrar tipos $\mathrm{Q}^{4}$ (en la red global 3D), $\mathrm{Q}^{3}, \mathrm{Q}^{2}$, $\mathrm{Q}^{1}$ y $\mathrm{Q}^{0}$ (para tetraedros aislados) en las especies presentes en fundidos de silicato. Por la composición se puede evaluar fácilmente el tipo de especie $\mathrm{Q}$ por el cálculo del parámetro integral NBO/T como una suma por todas las especies $Q^{i}(3)$,

\section{INTRODUCTION}

All properties of the silicate glasses and melts essential for their derivation in glass-ceramics through nucleation and crystallization process application critically depend on the internal structure. Like in the minerals basic structural unit of the alumosilicate melts is tetrahedra composed of network-forming components and oxygen. Melt framework is built of interconnected or polymerized tetrahedra. Degree of polymerization dictates transport properties such as viscosity and diffusivity, growth rates of the solid phases and so on. Arrangement of the silicate melts demonstrates partial ordering which is difficult to describe and characterize instrumentally. Given contribution is to overview some new unequivocal results in the spectral studies of the melt structure and to demonstrate how melting diagrams and crystallization kinetics data can be interpreted with the melt structure transition concepts. These consideration aid researchers in developing new glass-ceramics which can be used as valuable new building materials (1) (2).

\section{ORDERING IN SILICATE MELTS}

\subsection{Q Speciation}

At normal to moderate pressures network forming cations like silicon and aluminum are fourth coordinated with oxygen forming tetrahedra. This tetrahedra can be isolated like in the olivine structure or share common corner oxygens. By this feature one can distinguish different types of network-forming atom structural positions in accordance with the number of shared (or bridging) oxygen. It is the so-called $Q$ classification (3). We can find $Q^{4}$ (in the global $3 D$ network), $Q^{3}, Q^{2}, Q^{1}$ and $Q^{0}$ (for isolated tetrahedras) species in the melt. By the composition one can easily evaluate widely used integral parameter $N B O / T$ as a sum by all $Q^{i}$ species,

$$
N B O / T=\sum_{1=0.4}\left(4-n_{1}\right) x_{1}
$$


en donde NBO es el número de oxígenos- puente y $\mathrm{T}$ es el número de tetraedros por la unidad estructural. La especiación Q puede ser estudiada directamente por métodos espectroscópicos. Se puede obtener una información muy útil por espectroscopía de Infrarrojo (IR) estudiando los espectros en la gama de frecuencias entre $300-1.600 \mathrm{~cm}^{-1}$ (4). Básicamente consiste el espectro obtenido en dos de regiones, específicamente las bandas en la región $300-700 \mathrm{~cm}^{-1}$ correspondiente a un doblete de modos de oscilaciones. En la región $850-1.600 \mathrm{~cm}^{-1}$ se tienen los modos de estiramiento de la red. Generalmente, la superposición de varios modos forman picos asimétricos. Estudios previos de espectroscopía de IR en diversos fundidos se han realizado en las últimas décadas, lo que se ha confirmado por observaciones y cálculos teóricos. Para los fundidos de silicato alcalino la interpretación ha llegado a su punto más culminante. Así, en la Figura 1 puede verse, mediante medidas realizadas a elevadas temperaturas, el resultado de adaptar la banda asimétrica en la gama $800-1.250 \mathrm{~cm}^{-1}$ a la forma superpuesta de cuatro picos (5). A partir de estos datos se ha obtenidos los tipos de especies $Q^{4}$, $\mathrm{Q}^{3}$ y $\mathrm{Q}^{2}$ que predominan en el fundido de tetrasilicato. $\mathrm{El}$ área de los picos se supone que es proporcional al contenido correspondiente de cada tipo de especie o grupo estructural. Los datos totales se interpretan suponiendo que el equilibrio se desproporciona de la manera siguiente: where $N B O$ is the non-bridge oxygen number and $T$ is the number of tetrahedra per structural unit. The $Q$ speciation can be studied by the direct spectroscopic methods. Useful information can be achieved by studying IR spectra in the range of frequences $300-1.600 \mathrm{~cm}^{-1}$ (4). Basically it consists of two regions, namely bands in the region 300$700 \mathrm{~cm}^{-1}$ corresponding to bending modes of oscillations. In the region $850-1.600 \mathrm{~cm}^{-1}$ stretching modes of different type are located. Generally, there is overlapping of several modes forming asymmetric peaks. IR spectroscopy studies of the various melts continues for decades. By assigning to particular bonds is confirmed by theoretical calculations and observations. For the alkali-silicate melts interpretation has reached the state of art. In the plot of Figure 1 it can be seen through measurements done at high temperatures the result of fitting of asymmetric band in the range 800-1.250 $\mathrm{cm}^{-1}$ with four peaks (5). It folllows from the data obtained that $Q^{4}, Q^{3}$ and $Q^{2}$ species prevail in the tetrasilicate melts. Peaks area is assumed to be proportional to the corresponding species content. The whole data set is interpreted by assuming disproportionation equilibrium, as is shown in:

$$
2 Q^{3}=Q^{2}+Q^{4}
$$

Los diferentes valores de entalpía de reacción para las variedades de silicato de litio y potasio corresponden a tendencias térmicas diferentes en la formación de grupos Q. Para el silicato de litio (LS4) la entalpía de reacción es negativa con $\Delta \mathrm{H}=-33 \mathrm{~kJ} / \mathrm{mol}$, mientras para el silicato de potasio (PS4) es positivo (efecto endotérmico) con $\Delta \mathrm{H}=22 \mathrm{~kJ} / \mathrm{mol}$. De manera similar, el tetrasilicato de sodio se ha usado por Zotov y Keppler (6) para estudiar el mecanismo de disolución de agua en fundidos. Los resultados de sus espectros de IR en fundidos de tetrasilicato de sodio hidratado se dan en la Figura 2. Sobre la primera etapa de la disolución hasta un $6 \%$ de agua se observa una disminución del ordenamiento $\mathrm{Q}^{4} \mathrm{y}$ crecimiento de especies $Q^{3}$. Cuando el contenido en agua es mayor el contenido de especies $\mathrm{Q}^{3}$ se comienzan a transformar en $\mathrm{Q}^{2}$. En un fundido complejo de silicoaluminato la descomposición de los espectros en los intervalos de frecuencia en el que se detecta el agua de constitución no es posible.

\subsection{Distribución del tamaño de los anillos}

El orden medio alcance de una estructura de un fundido puede interpretarse en términos de anillos
Different enthalpy of reaction for lithium and potasium varieties corresponds to different thermal trends in the $Q$ speciation observed. For Lithium Silicate (LS4) composition enthalpy of reaction (2) is negative with $\Delta H=-33 \mathrm{~kJ} / \mathrm{mol}$, while for Potasium Silicate (PS4) it is positive (endothermic effect) with $\Delta H=22 \mathrm{~kJ} / \mathrm{mol}$. Similarly, the sodium tetrasilicate composition has been used by Zotov and Keppler (6) to study mechanism of water dissolution. Results of their IR study of hydrous sodium tetrasilicate glasses are depicted in the Figure 2. On the first stage of the dissolution up to $6 \mathrm{wt} . \%$ they observe a decrease of the $Q^{4}$ and growth of $Q^{3}$ species content. At the larger water content $Q^{3}$ species start to transform into $Q^{2}$. In the complex aluminusilicate melts reliable decomposition of the spectra in this frequency limits is not possible.

\subsection{Ring size distribution}

The medium range ordering of the melt structure can be interpreted in the terms of irreducible rings. The 

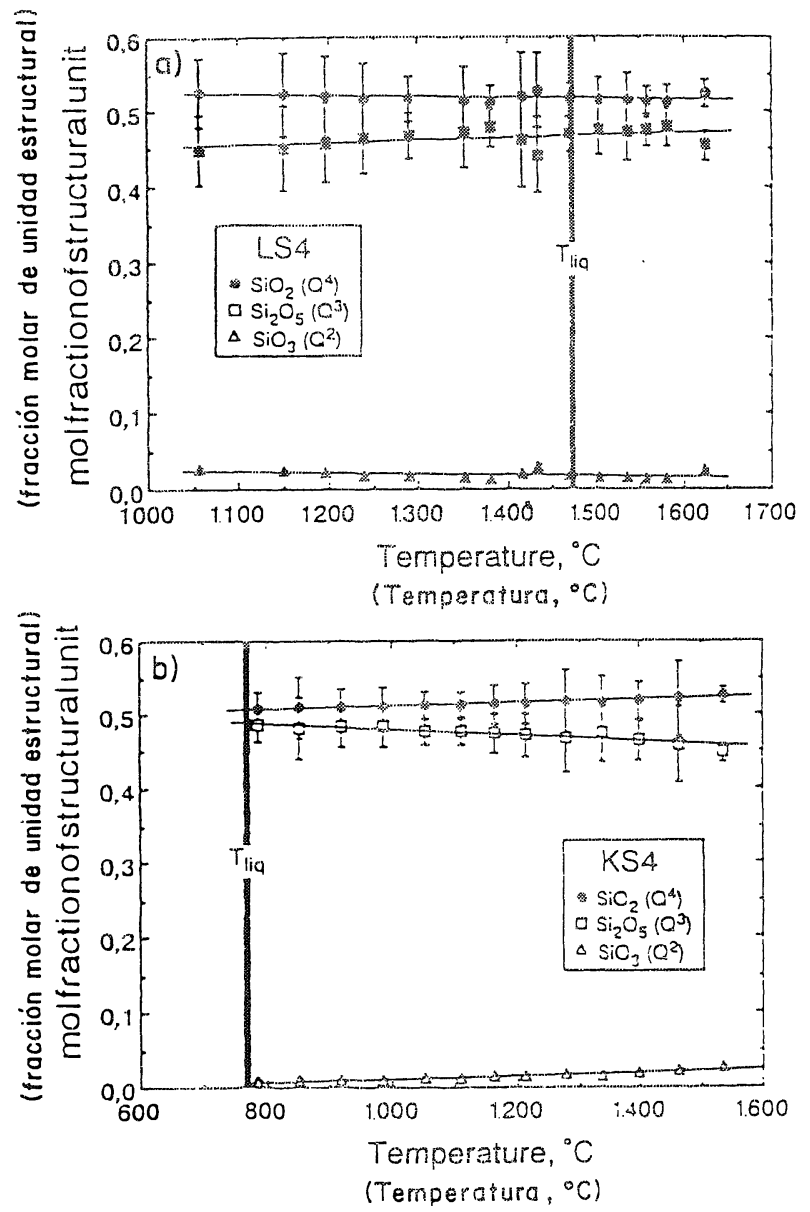

Figura 1.- Dependencia con la temperatura de las especies tipo $Q$ en fundidos de silicato: a) del silicato de litio ( $\mathrm{LS} 4$ ) y b) del silicato de potasio (KS4) (seguin Mysen y Frantz, 1993) (5).

Figure 1.- Temperature dependence of the $Q$ speciation: a) of the LS4 and b) KS4 (after Mysen and Frantz, 1993) (5).

irreducibles. La estructura altamente polimerizada de tales anillos es un problema topológico (7), pero en grados bajos de polimerización la presencia de anillos aislados puede predecirse. La deformación de los enlaces en ángulo tipo T-O-T implican un tipo de tensión inducido por la desviación del ángulo original que ha sido determinado, Mc Millan en 1984 (4). Para formar tres anillos miembros de la red es necesaria la desviación más grande de este ángulo. Por lo tanto, este estado de tensión da lugar modos de deformación con la frecuencia más alta. Sin embargo, se necesita una menor deformación para la introducción de 6 anillos miembros en la estructura del fundido. La asignación de las líneas del espectro IR en la gama de frecuencias $300-650 \mathrm{~cm}^{-1}$ es muy fiable, lo que se confirma con la observación de líneas individuales para algunas composiciones. El estudio teórico de la estabilidad y del espectro de IR de anillos individuales con oxígenos saturados en los vértices de hidrógeno ha sido hecho por métodos de química cuántica (8).

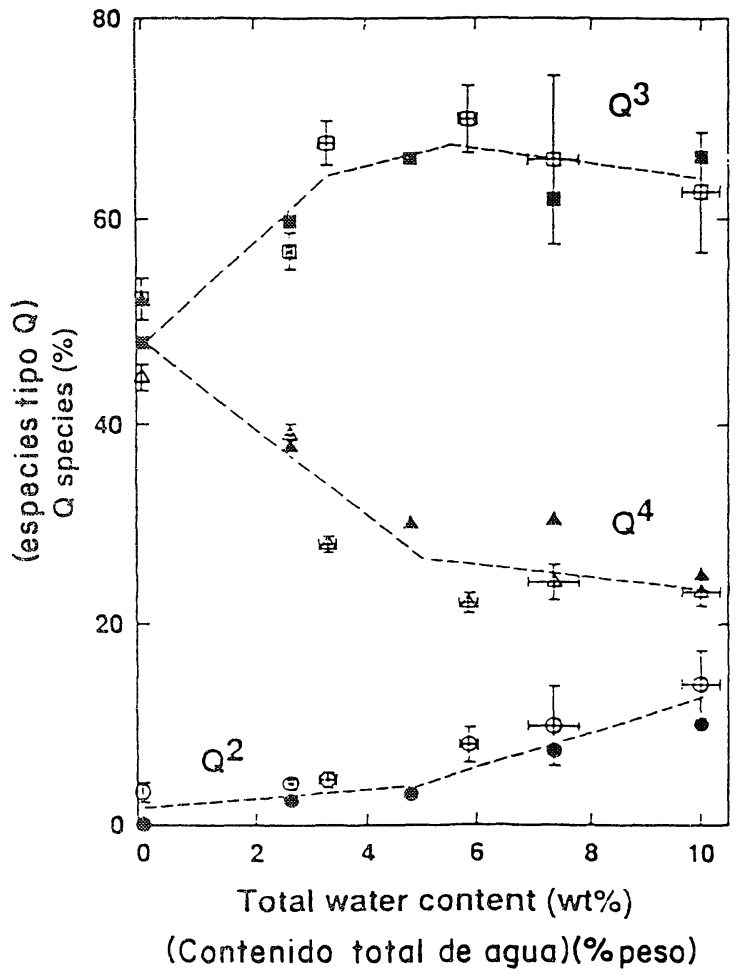

Figura 2.- Dependencia de las especies $Q$ en vidrios de silicato sódico (NS4) con el contenido de agua estructural en el vidrio (según Zotov y Keppler, 1998)(6).

Figure 2.- Dependence of the $Q$ speciation of NS4 glass on the water content (after Zotov and Keppler, 1998) (6).

structure of the highly polymerized melts definition of such rings is a topological problem (7), but at low degree of polymerization the presence of true isolated rings is anticipated. For bending of T-O-T bonds the degree of tension induced by deviation of the T-O-T bonds angle from tetrahedral was determined by Mc Millan in 1984 (4). To form three member rings the largest deviation is necessary. Therefore, this stress state gives rise to the bending mode with highest frequency. The less deviation is needed for 6 member rings. Assignment of the lines in IR spectrum in the range of frequencies $300-$ $650 \mathrm{~cm}^{-1}$ is very reliable. It is confirmed with observation of individual lines for some compositions. Theoretical study of the stability and $I R$ spectrum of individual rings with corner oxygen saturated with hydrogen has been done by methods of quantum chemistry (8). 
Recientemente, Simakin y col. (9) han investigado las especies de los anillos de vidrios sintéticos de AlbitaAnortita. Los espectros IR se descompusieron en dos o tres (cuando era posible) líneas anchas con el programa GRAMS (véase la Figura 3). Tres anillos miembros de red se detectan en el vidrio de anortita, mientras cuatro anillos miembros predominan para la composición mixta de ambos feldespatos vítreos. El miembro final de la Albita se compone principalmente en seis anillos que son miembros de la red (como en el caso de la tridimita). Esta diferencia se refleja en muchas de las propiedades de estos vidrios. La tendencia opuesta entre la cristalización de la albita y la anortita son bien conocidas.

Representando la solubilidad del Argon en función de la composición del fundido en el sistema $\mathrm{Ab}$-An es posible deducir la formación de los 6 anillos miembros de la red de manera que el aumento de la solubilidad se acompaña con un incremento del contenido total de 6 anillos miembros. Sólo los 6 anillos miembros de red tienen huecos suficientes capaces de acomodar el Argón. Este procedimiento sirve como método de comprobación de la correcta interpretación de los espectros de IR. La información sobre las proporciones de anillos en la red vítrea puede usarse para el análisis termodinámico del comportamiento térmico de este tipo de vidrios. La parte no-linear de la curva de solubilidad citada probablemente está relacionada con el comportamiento no-ideal de la solución de $\mathrm{Ab}-\mathrm{An}$. Este procedimiento de interpretación ha sido usado en nuestro caso para explicar el mecanismo de la disolución de agua en fundidos de granito.

Un ejemplo de la descomposición de las bandas de IR en las líneas que corresponden a los anillos miembros del tipo 6 y del tipo 4 se muestra en la Figura 3. Se ha encontrado una disminución sistemática del contenido de anillos tipo 4 miembro de los feldespatos con el aumento del contenido en agua (ver Figura 4 ). Esto explica el

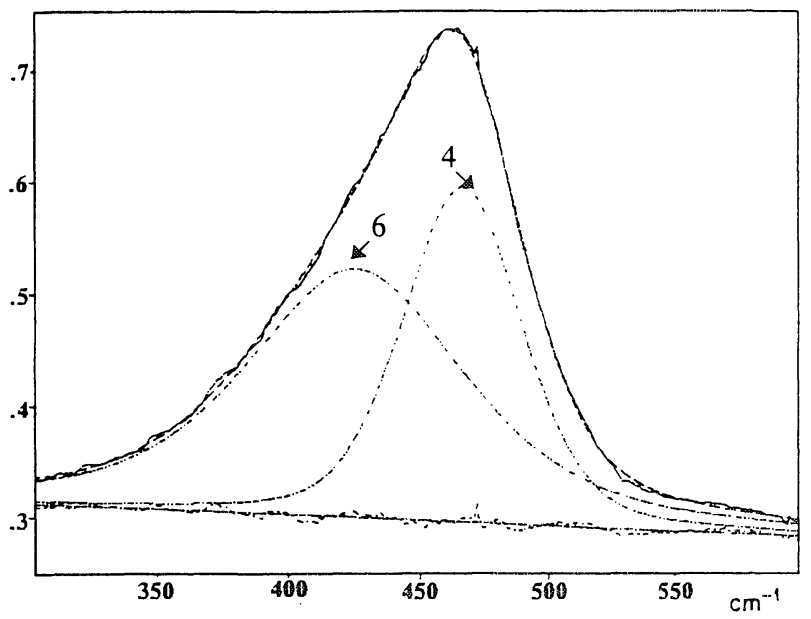

Figura 3.- Ejemplo de la descomposición de la banda asimétrica por espectroscopía IR del agua contenida en un vidrio de granito $\left(\mathrm{C}_{\mathrm{H} 2 \mathrm{O}}=4 \%\right.$ en peso) en el intervalo $300-700 \mathrm{~cm}^{-1}$ sobre las contribuciones de los anillos del tipo-6 y del tipo-4 (Simakin y col., 1998) (9).

Figure 3.- An example of the decomposition of asymmetric $I R$ band of the water bearing granite glass $\left(C_{\mathrm{H}_{2} \mathrm{O}}=4 \mathrm{wt} \%\right)$ in the range $300-700 \mathrm{~cm}^{-1}$ on the contributions of 6 and 4-member rings (Simakin et al., 1998) (9).
Recently, Simakin et al. (9) have investigated the ring speciation of the synthetic glasses of the AlbiteAnorthite composition. The IR spectra were decomposed into two or three (if possible) broad lines with GRAMS program (see Figure 3). Three member rings are detected in the anorthite glass, while four member rings predominate for this composition. Albite end member glass is composed mainly of six member (tridymite like) rings. This difference is reflected in many properties of these glasses. Opposite tendencies for crystallization of albite and anorthite are well known. By plotting the dependence of argon solubility as a function of melt composition in the Ab-An system it is possible to infer the formation of 6-membered rings. The increase of solubility accompanies the enhancement of the 6 member rings content. Only 6-member rings have central void size able to accommodate an Argon. This procedure serves as a test for correctness of our IR spectra interpretation procedure. The information on the proportions of the rings can be used for the thermodynamic analysis. Non-linear path of the fraction dependence probably is connected with non-ideal behavior of $A b-A n$ solution. Here has been applied this method to the analysis of the mechanism of water dissolution in the granite melt.

An example of the IR line decomposition into the lines corresponding to the 6-member and 4-member rings is shown in the Figure 3. It has been found a systematic decrease of the 4 member feldspar rings portion with increasing water content (see Figure 4). This explain the fact by the preferable hydration of

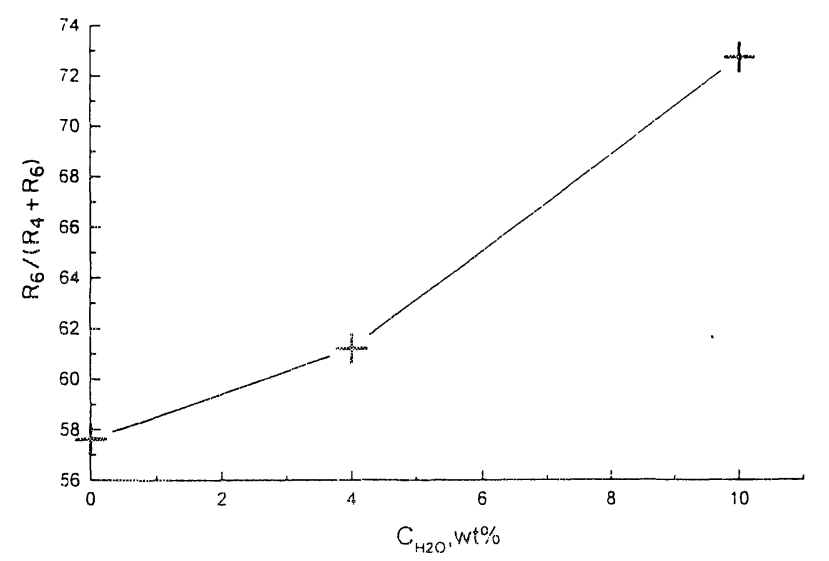

Figura 4.- Dependencia determinada por espectroscopia IR de la proporción de los grupos de anillos tipc-6 con el contenido de agua en un fundido de granito (Simakin y col., 1998) (9)

Figure 4.- Dependence determined by $I R$ of the proportion of the 6membered rings on the water content in the granite melt (Simakin et al., 1998) (9). 
hecho de la preferencia por la hidratación de los átomos de aluminio de la red vítrea en vidrios de aluminosilicato. Se ha confirmado además por otros métodos que el aluminio cambia su coordinación desde tetraédrica a octaédrica a altas presiones y por interacción con el agua.

\subsection{Entorno local de los cationes}

En la sección previa se ha discutido el orden de medio y corto alcance de fundidos de aluminosilicato, pero el efecto de los cationes modificadores de red en la red vítrea debe también tenerse en cuenta. Los métodos más útiles para investigar la coordinación local de los cationes son la Difracción de Rayos X y la Resonancia Magnética Nuclear (RMN). A partir de la DRX determinando la Función de Distribución Radial es posible conocer las distancias $\mathrm{M}-\mathrm{O}$ promedio en las posiciones existentes en la red . La técnica de RMN permite obtener información más precisa, como se ha demostrado muy recientemente por Zavel'sky y Salova (10). En la Figura 5a se muestra el espectro del isótopo $\mathrm{de}^{23} \mathrm{Na}$ en vidrios de silicato de sodio hidratado. Este espectro puede precisamente descomponerse en dos de picos. Uno, más amplio, corresponde a la posición menos simétrica del ion de sodio en el fundido. Sugerimos que en esta posición, el sodio se ubica más cerca de algún oxígeno en la red vítrea y que está enlazado por un enlace covalente polarizado. En la otra posición, que corresponde al otro pico, el átomo de sodio está rodeado por una "concha" de átomos de oxígeno, dando una señal más simétrica. Probablemente algún oxígeno del agua se involucra también en la coordinación del sodio en la posición simétrica. Este hecho se ve favorecido por el aspecto del agua molecular en las muestras que presentan un cambio de coordinación del sodio. Alguna cantidad de sodio que se desconecta de la red de alumina-sílice aumenta con la adición de agua (ver Figura 5b). El agua introducida en el fundido siempre interacciona con el mismo. En ausencia de cationes alcalinos (en fundidos de sílice pura ) sólo se encuentran grupos hidroxilo cuando existe un alto contenido en agua.

\section{DIAGRAMAS DE EQUILIBRIO EN FUNDIDOS DE FELDESPATOS}

Las relaciones de equilibrio entre fases en los sistemas de feldespatos se pueden interpretar en los términos de la estructura de fundidos discutidas en los apartados anteriores. El agua disuelta en un fundido de aluminosilicato actua, ante todo, con el aluminio y transforma los anillos de cuatro miembros de los feldespatos en anillos de seis miembros del tipo de la tridimita. La consecuencia de esta reacción es una disminución de la actividad del contenido de feldespato en el fundido. La resistencia de los feldespatos en este caso es diferente, siendo el menos estable el feldespato de sodio. La Figura 6 muestra varias gráficas de los diagramas aluminum atoms in the aluminosilicate network. It is also confirmed by other methods that aluminum is shifted from the tetrahedral to octahedral coordination at high pressures and by interaction with water.

\subsection{Local environment of the cations}

In the previous section the local and medium range arrangement for aluminosilicate network of melts has been characterized. The effect of cation modifiers of glassy network are worth of consideration too. Useful methods for investigating the local coordination of cations are X-Ray and NMR. From XRay methods one can get some mean coordination numbers and $M-O$ distance averaged by existing positions. The NMR method provides more precise information as was demonstrated very recently by Zavel'sky and Salova (10). In the Figure $5 a$ the spectrum of ${ }^{23} \mathrm{Na}$ isotope in the hydrous sodiumsilicate glass is depicted. It can be accurately decomposed into two peaks. Wider one corresponds to the less symmetrical position of the sodium ion in the melt. We suggest that in this position the $\mathrm{Na}^{+}$is located closer to some particular oxygen in the silicate network and connects with it by covalent polarized bonding. At another position the sodium atom is surrounded by the oxygen shell and gives more symmetric signal. Probably some water oxygen are also involved in the coordination of sodium in the symmetric position. This suggestion is favored by the appearance of the molecular water in the samples demonstrating sodium coordination transfer. Some amount of sodium disconnected from the alumino-silica network increases with addition of water (see Figure 5b). Water in the melt always interact with the melt. In the absence of alkali cations (in the pure silica melt) only hydroxile groups are found at high water content.

\section{MELTING DIAGRAMS WITH FELDSPARS}

The phase relation in the feldspars systems can be interpreted in the terms of the melt structure. As it was discussed above, water dissolved in the aluminosilicate melt interacts first of all with aluminum and transform four-member feldspar rings into tridymite like 6-member ones. The consequence of this reaction is a decrease of the activity of the feldspar component content in the melt. Resistance of particular type of feldspars is different, being the less stable the sodium feldspar. The Figure 6 shows 


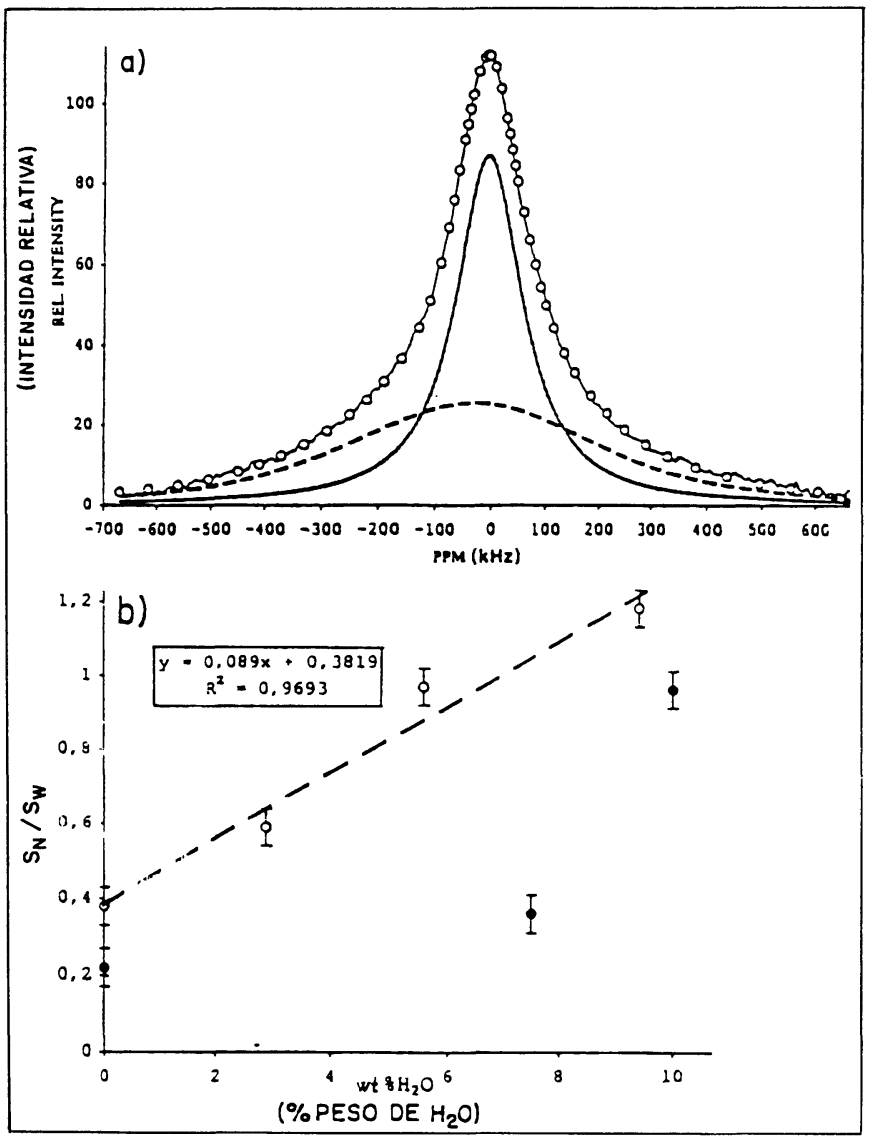

Figura 5.- a) Espectro de $\mathrm{RMN}$ del $\mathrm{Na}^{23}$ en la partición de las dos posiciones del sodio en un fundido hidratado de silicato de sodio (Zavel'sky y Salova 1999) (10). b) Descomposición de la señal en el caso de las lineas estrecha (posición simétrica) y ancha (posición asimétrica).

Figure 5.- a) NMR treatment of the ${ }^{23} \mathrm{Na}$ partitioning between two positions in the sodium-silica hydrous melt (Zavel'sky and Salova. 1999) (10). b) Signal decomposition on the narrow (symmetrical site) and wide (asymmetrical site) lines.

de fusión tipo eutéctico del sistema Albita $\left(\mathrm{NaAlSi}_{3} \mathrm{O}_{8}\right)$ Cuarzo $\left(\mathrm{SiO}_{2}\right)$ a presiones diferentes de agua (11) (12). El punto eutéctico en este caso es función de la acción competitiva del contenido en agua y la temperatura sobre la estabilidad de las especies de feldespato en el fundido. Una temperatura más alta, probablemente, favorece la descomposición de los feldespatos con anillos tipo-4 de la misma manera que la adición de agua. El agua da lugar a una disminución de la temperatura del eutéctico actuando sobre la descomposición de las especies de feldespato. Este cambio en el sistema Albita-Q es mayor que en el Ortosa-Cuarzo. La mayor estabilidad de los anillos tipo-4 de la Ortosa, cuatro anillos de miembro en el fundido, se expresa también por el hecho de que la Ortosa se expresa también a causa de que los anillos tipo-4 y tipo-6 del fundido de Ortosa sufren tensiones que dan lugar a la cristalización de leucita. Mientras que en el caso de los fundidos de albita predominan los anillos tipo tridimita. El cambio del punto eutéctico en el sistema Anortita-Q es también importante con la presencia de agua, pero se relaciona probablemente con la cantidad mayor de alúmina ( que es el átomo sobre el que actúa el agua) en este mineral. Las mismas tendencias tienen lugar en sistemas ternarios. El cambio de la composición del

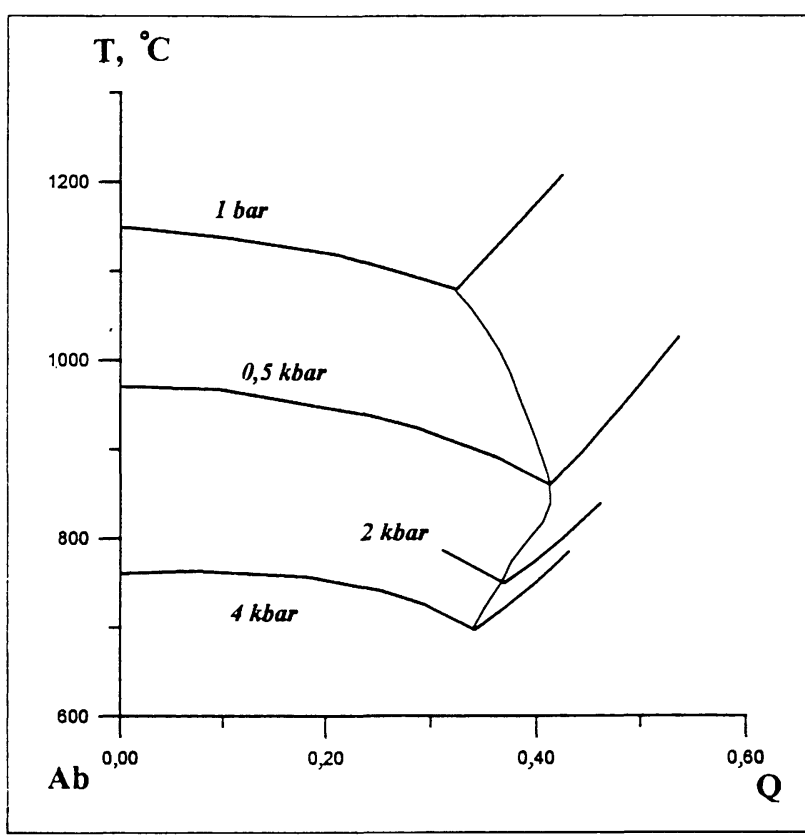

Figura 6.- Trayectoria del punto eutéctico en el sistema Albita-Cuarzo con diferentes presiones de vapor de agua (según Kuznetcov y Epel'baum, 1985)(12)

Figure 6.- Trajectory of the eutectic point in the system $A b-Q$ at different water pressures (after Kuznetcov and Epel'baum, 1985) (12)

several plots of the eutectic type melting diagrams (11) (12) in the Albite ( $\mathrm{NaAlSi}_{3} \mathrm{O}_{8}$ )-Quartz $\left(\mathrm{SiO}_{2}\right)$ system at different water pressures. The eutectic point appears designed in this case due to competitive action of the temperature and water content on the stability of the feldspar species in the melt. Higher temperature, probably, favors the decomposition of 4-member feldspar rings in the same way as water addition. While water leads also to the decreasing of the eutectic temperature and its effect on the feldspar species decomposition. The shift in the system $A b-Q$ is larger than in the Orthoclase-Quartz system. Larger stability of the Or four member rings in the melt is expressed also by the fact that Or melt leucite constrains both with six and four member rings crystallizes. While tridymite like rings predominate in the pure albite melt. The eutectic shift in the An- $Q$ system is also large, but it is probably connected with enlarged amount of alumina (target for water) in the composition of this mineral. The same tendencies are revealed in the ternary system. Shifting of the eutectic composition to the albite corner is evident. This effect is increased with addition of the acid components (like fluorine 
eutéctico en el vértice de la albita es también evidente con el contenido en agua del fundido. Este efecto aumenta con la adición de los componentes ácidos (como ácido flúorhídrico) en el fundido. La misma tendencia se encuentra en la secuencia de las intrusiones de granito que se forman por cristalización fraccionada en algunas cárnaras de magma en la corteza terrestre.

\section{NUCLEACIÓN Y CRECIMIENTO DE FUNDIDOS ORIGINALES DE SILICATO PARA LA PRODUCCIÓN DE MATERIALES VITROCERÁMICOS}

\subsection{Cinética de la cristalización de vidrios de silicato de litio}

Resultados valiosos sobre la determinación simultánea de la cinética de nucleación y crecimiento en vidrios de óxido de sodio- cal-sílice y óxido de litio-sílice fueron obtenidos en 1979 por González-Oliver y col. (13). Estos autores sugieren que la velocidad de crecimiento cristalino en este tipo de vidrios aumenta con la disminución de viscosidad ocasionada por la adición de agua. Pero una observación más detallada de estos resultados muestran que la magnitud de esta variación es menor que la variación de la viscosidad. Una disminución del máximo de la velocidad de crecimiento se relaciona con una disminución en los coeficientes de transporte por difusión en la red de los componentes formadores de red en estos fundidos. Es bien conocido por datos experimentales que los coeficientes de difusión en fundidos de silicato no son proporcionales a la viscosidad. La ecuación de Eyring para tamaños variables de especies difusivas se aplica generalmente con la interpretación de los datos de difusión (14). Suponiendo que el tamaño de las especies estructurales de la red vítrea están asociados con la viscosidad, esta ley puede ser reformulada como una ley potencial de la viscosidad con un exponente $\mathrm{k}$ : acid) to the fluid. These trends can be met in the sequence of granite intrusions formed at the fractional crystallization of some larger magma chambers.

\section{NUCLEATION AND GROWTH OF ORIGINAL SILICATE MELTS FOR PRODUCING GLASS-CERAMICS}

\subsection{Kinetics of the crystallization from the lithia- silica glasses}

Valuable results on the simultaneous determination of the nucleation and growth kinetics in the sodalime-silica and lithia-silica glasses and correspondent viscosities measurements were reported in 1979 by Gonzalez-Oliver et al. (13). They suggest that crystal growth rate is increased in proportion with the viscosity decrease caused by water addition. But a closer view shows that in this case the variation of the growth rate is less than variation in the viscosity of glasses. After maximum decrease of the growth velocity is connected with a decrease of the diffusion transport coefficients of network forming components in the melt. But it is quite well known from experimental data that diffusion coefficient in silicate melts and is not proportional to the viscosity. The Eyring equation with variable diffusive species size is generally applied while dealing with interpretation of diffusion data (14). By assuming that species size is associated with viscosity, this law can be reformulated as a power law of viscosity only with some $k$ exponent:

Esta aproximación es muy directa para el caso de polímeros orgánicos con una longitud variable de moléculas. Ambos coeficientes de difusión y de viscosidad se ha comprobado que son función de la longitud de las cadenas moleculares, pero con diferentes exponentes:

$$
D=\frac{B}{\eta^{k}}, k<1
$$

This approach becomes straightforward for the organic polymer melts with variable length of molecules. Both diffusion coefficient and viscosity are found to be the power functions of the length (l) but with different exponents

$$
D \propto 1^{-2}, \quad \eta \propto 1^{3} \text { or } 4
$$

Cuando no se conoce la longitud, entonces el coeficiente de difusión es inversamente proporcional a la viscosidad en un orden exponencial de aproximadamente: 0,6 . Así, pues, la variación en el caso de fundidos de silicato es más complicada ya que no hay un tamaño sencillo para caracterizar las

Unknown variable length can be excluded, then diffusion coefficient will be inversely proportional to the viscosity in the order about 0.6. The situation in the silicate melts and glasses is more complicated since not a single size is to characterize the aluminosilica network units. Lifetime of this units is 
unidades reticulares de alúmina-sílice. El tiempo de vida de estas unidades también está limitado. Sin embargo, el mismo proceso que conduce a la nucleación homogénea de la fase sólida es el responsable del cambio en la estructura durante el enfriamiento. Una manera diferente para definir la difusividad en función de la viscosidad fué elaborada por Simakin en 1993 (15). Se usaron en este caso las denominadas leyes empíricas de compensación de la difusión y la viscosidad. Estos datos caracterizan los parámetros de las representaciones de Arrhenius en las temperaturas de sobre-liquidus. Se ha encontrado para una serie de fundidos altamente polarizados que los diferentes factores pre-exponenciales de ambas propiedades son función de las correspondientes energías de activación. Por tanto, se sugiere que un fundido subenfriado a diferentes temperaturas por debajo de la de liquidus tiene unos estados estructurales diferentes. Esto se ha demostrado por el comportamiento no-Arrheniano de la viscosidad y difusión en estos casos. Los valores de viscosidad son, entonces, de tipo Arrhenius, pero corregidos por una variable pre- exponencial y por la energía de activación. Así, aplicando la ley empírica de compensación se puede encontrar la verdadera energía de activación con la dependencia de la temperatura con la viscosidad. Estos valores son generalmente menores que los obtenidos a partir de la energía de activación aparente por diferenciación de $\eta / 1 / T)$. Así, pues, suponiendo que la energía de activación de la difusión y la viscosidad son las mismas (o cercanas) se puede evaluar el coeficiente de difusión por la estimación del factor pre-exponential mediante la ley correspondiente de compensación. La ley potencial para $D(\eta)$ para $\mathrm{k}<1$ es apropiada para representar esta estimación, por ejemplo, en el caso de fundidos de anortita.

Relaciones similares se pueden obtener de los datos que se han referenciado al comienzo de este apartado. Así, las Figuras 7a y 7b muestran la variación de las velocidades de crecimiento con la viscosidad para fundidos con 0,02 (L1) y 0,136 (L5) \% en peso de agua. La viscosidad ha sido recalculada en la gráfica de $\log (\eta)$ frente a $1 / \mathrm{T}$ a partir de los datos de González-Oliver y col (13). Para una mejor comparación, los datos de velocidad se han transformado en $-\log (\mathrm{U} / 1000)$. Es evidente que la pendiente de la viscosidad es mayor en el caso de ambas composiciones vítreas. En la Figura 8 pueden verse los resultados de la evaluación de la velocidad de crecimiento cristalino del silicato de litio en la composición L5. Usando los datos de crecimiento de la composición $\mathrm{Ll}$ y corrigiendo los mismos para una razón de viscosidad de 0,7 se llega a la expresión: also limited. However, the same process leading to the homogeneous nucleation of the solid phase are responsible for the change in the internal structure at cooling. Somewhat different way to define diffusivity versus viscosity relationship was elaborated by Simakin in 1993 (15). Empirical socalled compensation laws for diffusion and viscosity were used. These data characterize parameters of their Arrhenius representations at superliquidus temperatures. It was found that for the set of highly polymerized melts with different composition preexponential factors for both properties depend on the correspondent activation energies. Therefore, it was suggested that a supercooled melt to different temperatures below liquidus has a different structural states. It is demonstrated by the nonArrhenius behavior of viscosity and diffusion. The values of viscosity were approximate as an Arrhenius behavior with variable pre-exponent and activation energy. Thus, while applying empirical compensation law it can be found true activation energy from the temperature dependence of the viscosity. These values are generally lower than apparent activation energy obtained by differentiation of the $\eta(1 / T)$. Then by assuming that activation energy of the diffusion and viscosity are the same (or close) can be evaluated the diffusion coefficient by estimation of the pre- exponential factor through correspondent compensation law. Power law for $D(\eta)$ with $k<1$ is suitable to represent these estimates e.g. for anorthite melt.

Similar relations follow from the data referenced in this section. On the Figure $7 a$ and $7 b$ growth rates and viscosities for the melts with 0.02 (L1) and 0.136 (L5) wt.\% of water are shown. The viscosity was recalculated in the, $1 / T$ coordinates from GonzalezOliver et al. data (13). For better comparison velocity values are transformed as -log (U/1000). It is evident that slope of the viscosity is larger for both compositions. On the Figure 8 results of the evaluation of the growth rate for lithium silicate composition L5 are shown. By using growth data for L1 composition and correcting by viscosity ratio in the order 0.7 it can be deduced the following equation:

$$
U(T)=U_{o}(T)\left(\frac{\eta_{0}(T)}{\eta(T)}\right)^{k}, \quad k=0.7
$$


Se ha usado para llegar a esta expresión una aproximación logarítmica no lineal de la viscosidad en función de $1 / \mathrm{T}$. La correspondencia es buena para los datos calculados y medidos en la región de los intervalos solapados de temperatura para las composiciones L1 y L5. La desviación a menores temperaturas puede atribuirse a que la viscosidad puede aproximarse como función lineal de la inversa de la temperatura absoluta sólo localmente. Por tanto, ningún efecto particular del agua puede distinguirse en este caso. Como se mencionó antes la disolución de agua en fundidos de sodio tetra-silicato y tri-silicato no afecta al cambio en las especies de anillos estructurales. Los datos de crecimiento confirman únicamente que una pequeña cantidad de agua sólo cambia la viscosidad por una des-polimerización parcial pero no afecta en este caso a la distribución de las unidades de crecimiento cristalino.

\subsection{Velocidades de crecimiento de feldespatos a partir de fundidos hidratados}

Los modelos estructurales pueden ser útiles para comprender la cinética de nucleación de los feldespatos y el crecimiento cristalino en fundidos de granito. Así, la menor capacidad de nucleación del fundido de albita que usualmente se transforma en tridimita con estructura de anillos tipo-6 en la fusión es comparada con la de la anortita que mantiene la estructura de anillos tipo-4 (17).

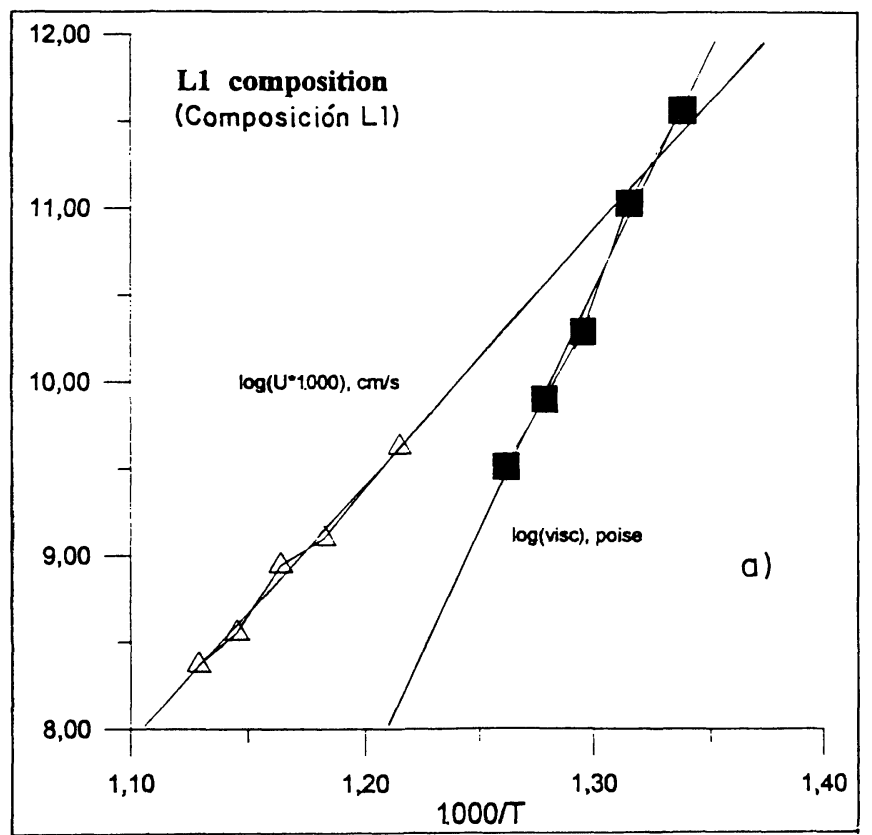

Local linear logarithmic approximation for viscosity as a function of $1 / T$ was used. Good correspondence observed for the calculated and measured data in the region of the overlapped temperature intervals for L1 and L5 compositions. Deviation at lower temperature can be attributed to the fact that viscosity can be approximated as linear function of inverse absolute temperature only locally. Therefore, no particular effect of water can be distinguished in this case. As it was mentioned above at the water dissolution in the sodium tetra-silicate and threesilicate melts $Q$-speciation is changed but ring speciation is not affected. The discussion growth data confirms that small quantity of water only changes viscosity by the partial de-polymerization but does not affect the growth units distribution.

\subsection{Growth rates of feldspars from hydrous melts}

Structural models can be useful to understand the kinetics of feldspar nucleation and growth from granite melts. Thus, the lower nucleation capability of the albite melt which usually transfors into tridymite like 6-membered ring structure at the melting as compared with anorthite which maintains its feldspar 4-membered rings (17).

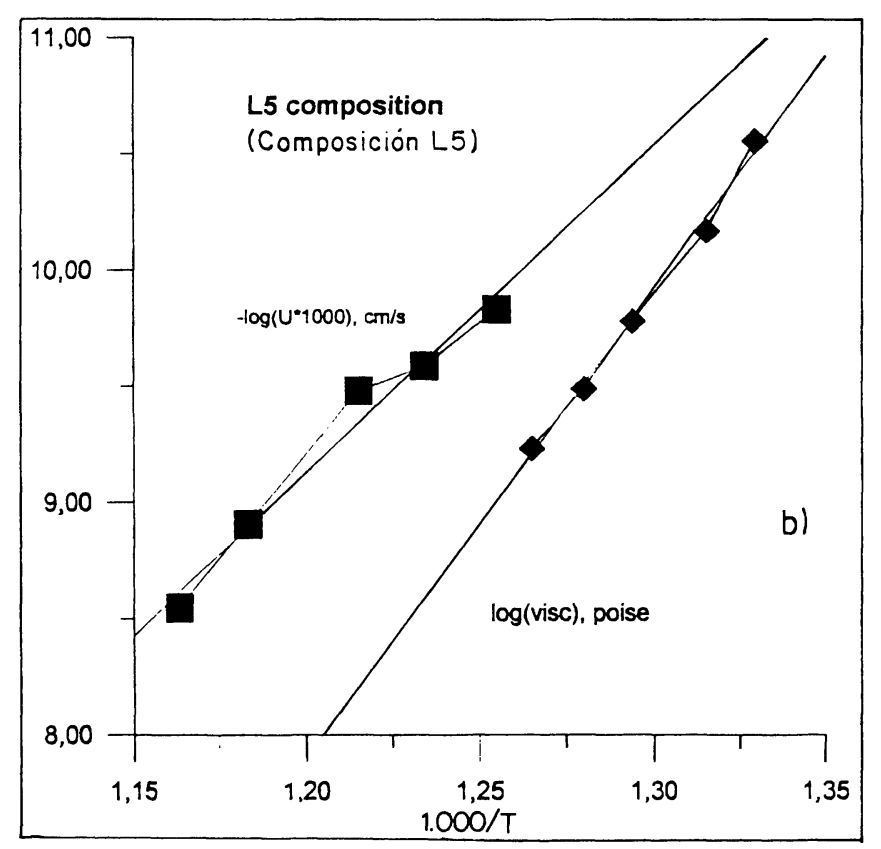

Figura 7.- Dependencia de la viscosidades y velocidad de cristalización en el caso de vidrios de silicato de litio (composición LS2) con un contenido bajo en agua. Se muestran las viscosidades y velocidades de crecimiento (log $\eta$, poises) en función de la inversa de la temperatura. Las velocidades de crecimiento se han transformado como - $\log (\mathrm{U} / 1000)$ para comparar directamente las pendientes de ambas dependencias en una misma gráfica. a) Composición L1 (0,02 $\%$ en peso de agua) y b) composición L5 (0,136 \% en peso de agua) (según González-Oliver y col., 1979) (13).

Figure 7.- Dependence of the crystallization rates and viscosities for the lithium silicate glasses (LS2) composition with a small water content. Growth velocities and viscosities (log (D), poise) as a function of the inverse temperature are shown. Growth velocities are transformed as -log(U/I000) to compare slopes of the both dependencies on the one plot. a) $\mathrm{LI}\left(0.02 \mathrm{wt} \% \mathrm{H}_{2} \mathrm{O}\right)$ and b) $\mathrm{L5}\left(0.136 \mathrm{wt} \% \mathrm{H}_{2} \mathrm{O}\right)$ (according to Gonzalez-Oliver et al., 1979) (13). 


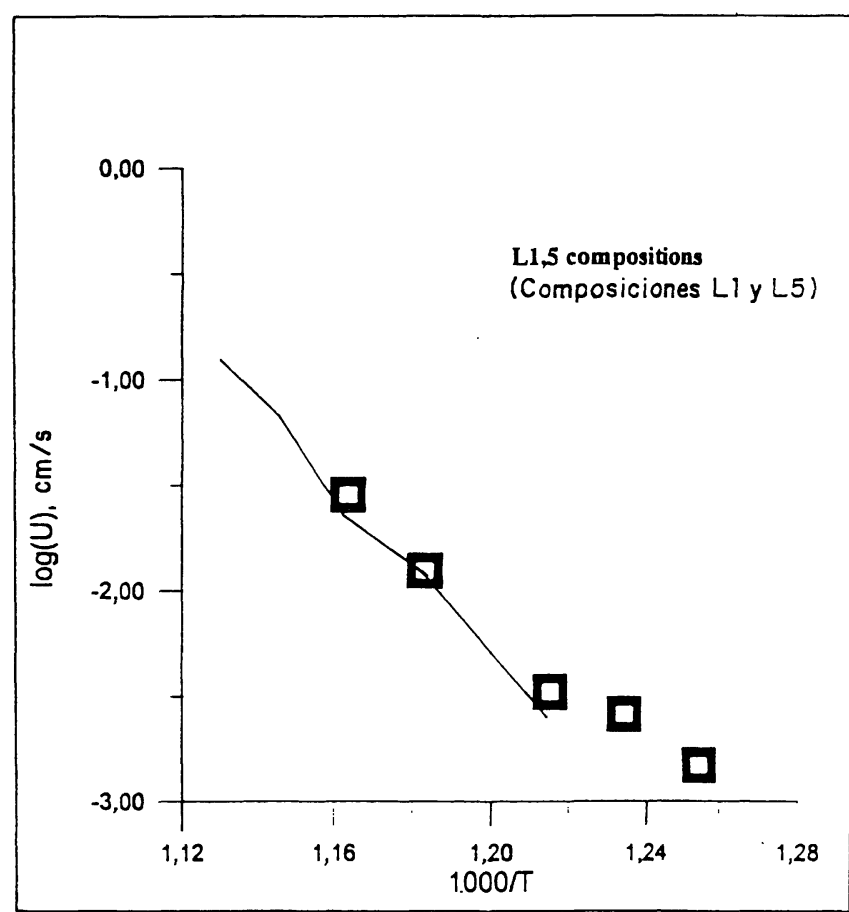

Figura 8.- Razón de la viscosidad calculada en el orden $k=0,7$ y datos experimentales de la velocidad de crecimiento cristalino de la fase LS2 para el mayor contenido en agua (composición L5) ( según González- Oliver y col., 1979)(13).

Figure 8.- Calculated viscosity ratio while using the order $k=0.7$ and experimental data on the crystal growth rate of LS2 phase at higher water content (composition L5) (according to Gonzalez-Oliver et al., 1979) (13).

El efecto del agua disuelta en el fundido de feldespatos y en sus velocidades de crecimiento cristalino ha sido estudiado por Simakin y Chevychelov (1995) (16) para el crecimiento del feldespatos alcalinos mixtos (solución sólida de sanidine $\mathrm{KAlSi}_{3} \mathrm{O}_{8}$ y albite $\mathrm{NaAlSi}_{3} \mathrm{O}_{8}$ ) desde fundidos de granito hidratados. En esta investigación el método de "sembrado" de cristales ha sido aplicado, obteniéndose los datos cinéticos desde el enfriamiento brusco de vidrios experimentales a diferentes velocidades de enfriamiento. Las experimentaciones se efectuaron a presión constante de 1 kbar y contenido de agua cerca de la saturación (4\% en peso), así como también en condiciones subsaturadas de agua. En la etapa inicial (lejos del equilibrio), se observó una dependencia lineal de la longitud máxima de los cristales en función del tiempo disminuyendo después con la velocidad de crecimiento. El valor máximo inicial se usó para diseñar la dependencia del subenfriamiento con el valor de crecimiento (ver Figura 9).

Muncill y Lasaga (18) han estudiado también la cinética del crecimiento de plagioclasas en el sistema hidratado de $\mathrm{Ab}-\mathrm{An}\left(\mathrm{NaAlSi}_{3} \mathrm{O}_{8}\right)$ a presiones de agua de 3 y 5 kbar. Han usado el método de "sembrado" con cristales y enfriamiento brusco como en la investigación citada anterior (17). Ambos

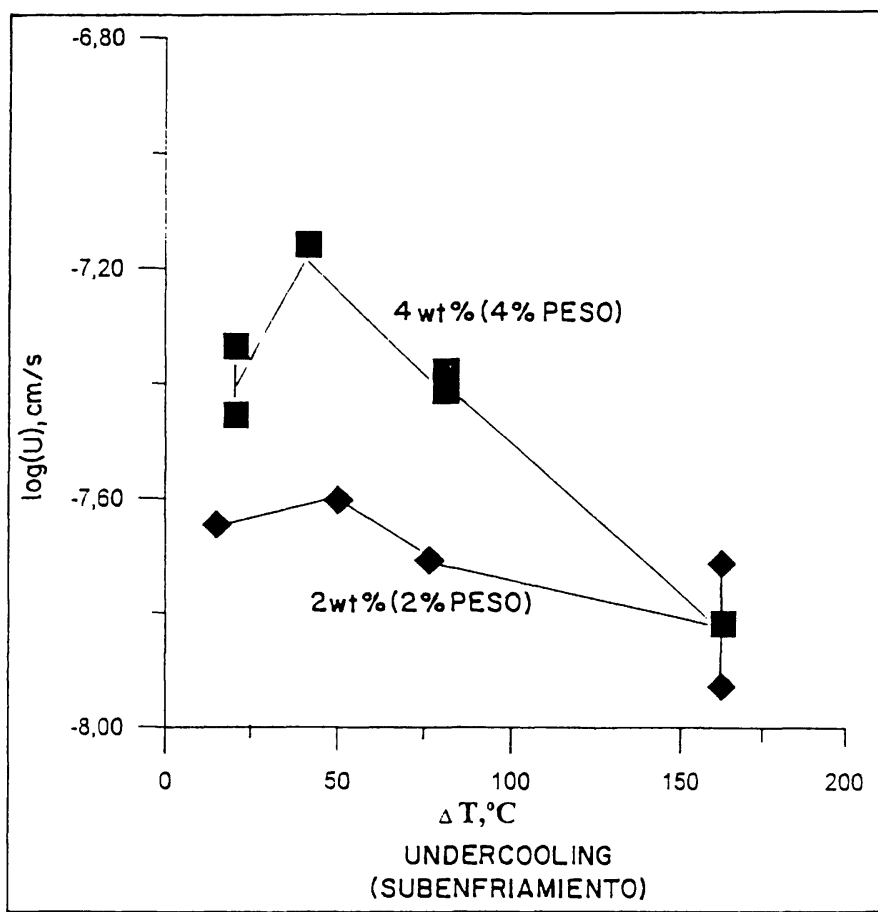

Figura 9.- Dependencia de la velocidad de crecimiento cristalino en función del grado de subenfriamiento $\left(\Delta \mathrm{T} \mathrm{en}{ }^{\circ} \mathrm{C}\right)$ para feldespatos alcalinos en fundidos de granito en el caso de contenidos de agua del 2 y $4 \%$ en peso (Simakin y Chevychelov, 1995) (13).

Figure 9.- Undercooling dependence $\left(\Delta T\right.$ in $\left.{ }^{\circ} \mathrm{C}\right)$ of the growth rates of the alkali feldspar from the granite melt with water content 2 and $4 w t \%$ (Simakin and Chevychelov, 1995) (13).

The effect of water dissolved in the melt of feldspars and their growth rates were reported in the past by Simakin and Chevychelov (16) for the growth of the mixed alkali feldspars (solid solution of sanidine $\mathrm{KAlSi}_{3} \mathrm{O}_{8}$ and albite $\mathrm{NaAl} \mathrm{Si}_{3} \mathrm{O}_{8}$ ) from hydrous granite mels. In this investigation the seeds method was applied, obtaining the kinetic data from quenching of experimental glasses after different cooling rates. Experiments were carried out at constant pressure equal tol $\mathrm{kbar}$ and water content close to the saturation (4 wt\%), as well as in water undersaturated conditions. At initial stage (far from equilibrium), the linear dependence of the maximum crystal length versus time was observed and a later decreases of the growth rate. The initial maximum value was used to design the undercooling dependence with the growth rate (see Figure 9).

Muncill and Lasaga (18) have studied also the growth kinetics from plagioclases in the hydrous $A b$ $\mathrm{An}\left(\mathrm{NaAlSi}{ }_{3} \mathrm{O}_{8}-\mathrm{CaAl}_{2} \mathrm{Si}_{2} \mathrm{O}_{8}\right)$ system at water pressures of 3 and 5 kbar. They also have used the seeding method and quenching for time snap shots as in the former cited investigation (17). Both investigations 
investigadores encontraron que existe una débil dependencia de la velocidad de crecimiento de estos feldespatos con el contenido en agua en los fundidos originales.

La velocidad de crecimiento cristalino depende de la viscosidad del fundido y de la concentración de especies cristalinas "sembradas". Usando estas especies como agentes nucleantes se puede rebajar la barrera de activación para el crecimiento de la cristalización. La aniquilación de anillos del tipo-4 en el fundido de granito es probablemente el responsable, en este caso, de la insensibilidad observada de la velocidad de crecimiento con el contenido en agua. $\mathrm{La}$ viscosidad y concentración de componentes feldespáticos tienen un efecto opuesto actuando como un mecanismo de compensación.

\subsection{Influencia sobre el nucleación del agua disuelta en el fundido}

La mayor influencia del agua incluída en fundidos sobre la nucleación de fases de silicatos proviene de la fuerte influencia del contenido en agua sobre la energía superficial $(\sigma)$ de la interfase cristal/ fundido en la ecuación de nucleación que es proporcional a $\exp \left(-\sigma^{-3} \cdot k(\Delta T)\right)$. Hay datos experimentales que demuestran que ese agua disminuye fuertemente la energía de superficie de la interfase fluído/ fundido, por lo que un efecto similar es de esperar también para la interfase cristal/fundido. El efecto de la primera adición de agua en un $0,1 \%$ en peso sobre la nucleación homogénea del disilicato de litio (LS2) puede ser ilustrado con los datos de González-Oliver y col. (13). No llevan a cabo experimentos cinéticos con varias duraciones, pero usan la razón de la densidad de núcleos en volumen al tiempo de tratamiento térmico como estimación mínima de la velocidad de nucleación. En la Figura 10 se recogen los datos de los fundidos con 0,02 y $0,132 \%$ en peso. Se puede ver que la velocidad de nucleación máxima aumenta más de 10 veces mientras que la temperatura del máximo cambia desde $465^{\circ} \mathrm{C}$ a $430{ }^{\circ} \mathrm{C}$. Este cambio en la temperatura del pico se relaciona probablemente con la disminución de la temperatura de liquidus con la adición de agua (16). Simakin y Chevychelov (16) han investigado además el tiempo de retraso de la velocidad de crecimiento de feldespatos sobre "semillas" de cristales de composición similar con el contenido de agua en fundidos de granito. Han encontrado en los numerosos experimentos de "quenching" o enfriamiento brusco del fundido que los cristales crecen con cierto "retraso", comprobando que el tiempo de demora o retraso es inversamente proporcional a la nucleación heterogénea. En subenfriamientos en el intervalo de $30^{\circ} \mathrm{C}-60^{\circ} \mathrm{C}$ cambia desde 3-5 horas, con un contenido en agua del have shown a very week dependence of different feldspars growth rate with the water content.

The growth rate depends on the viscosity of melt and concentration of crystal-like species in the melt. By using this species as nucleation agents can be lowered the activation barrier for the growth of crystallization. Annihilation of the 4-membered rings in the granite melt is probably responsible for the observed insensitivity of the growth rate to the water content. Viscosity and concentration of feldspar components have opposite effect acting as compensation mechanism.

\subsection{Influence on the nucleation of the dissolved water in the melt}

Water has a much larger influence on the nucleation of the silicate phases from the melt arises from the very strong influence of surface energy $(\sigma)$ of the crystal/melt interface on the nucleation rate proportional to the $\exp \left(-\sigma^{3} k(D T)\right)$. There are experimental data demonstrating that water strongly diminish the surface energy of the fluid/ melt interface, similar effect can be expected also for the crystal/melt interface. The effect of the first water addition (0.1 wt\% of water) on the homogeneous nucleation of the LS2 phase from lithium silicate melts can be illustrated with data from GonzalezOliver et al., 1979 (13). They have not carried out kinetic experiments with several duration but use ratio of the volume nuclei density to the exposure time as minimum estimate of nucleation rate. On the Figure 10 data for the melt with 0.02 and $0.132 \mathrm{wt} \%$ water are shown. One can note that maximum nucleation rate increases more than 10 times while temperature of the maximum is shifted from $465^{\circ} \mathrm{C}$ to $430^{\circ} \mathrm{C}$. Shifting of the peak temperature is probably connected with a decrease of the liquidus temperature with the water addition. Simakin and Chevychelov (16) have investigated the delay time of the growth of feldspars on the seeds of similar composition while changing water content of the granite melt. They have found in the numerous quenching experiments with different runs duration that crystals start to grow with some delay. The delay time is inversely proportional to the heterogeneous nucleation rate. At undercooling in the $30-60^{\circ} \mathrm{C}$ range it changes from 3-5 hours at water content of 
4\% peso a 4-5 días para un contenido de agua sobre $0,7 \%$ en peso (ver Figura 11 ). Por lo tanto, se puede esperar que, en general, el agua contenida en el fundido original facilite la cristalización de fundidos formadores de vidrio aumentando las densidad del número de cristales y produciendo materiales vitrocerámicos y petrúrgicos con pequeños tamaños de grano.

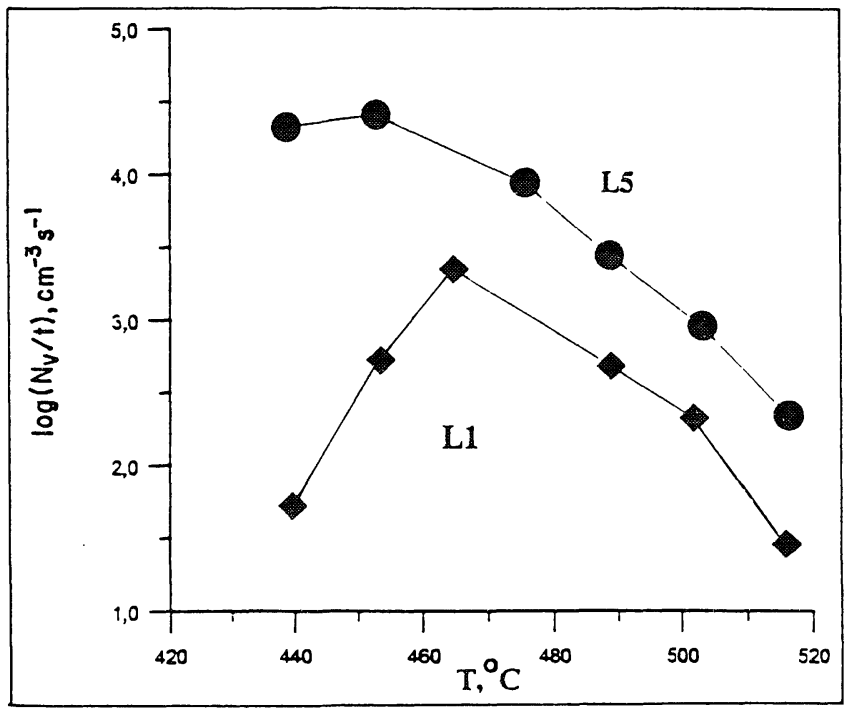

Figura 10.- Velocidad de nucleación de la fase de disilicato de litio (LS2) para dos contenidos de agua: círculos cuadrados, composición Ll y círculos, composición L5 (13).

Figure 10.- Nucleation rates of the LS2 phase for two water contents: square circles, L1 composition; circles, L5 composition (13).

\section{CONCLUSIÓN}

Los fundidos de granito de composiciones de aluminosilicatos son comunes en la preparación de materiales de construcción de tipo vitrocerámico puesto que son abundantes en la naturaleza. La cinética de nucleación y cristalización de las fases cristalinas que se obtienen a partir de estos fundidos determina el grado de cristalinidad y microestructura de los productos finales (1) (Rincón, J.M. y Romero, 1996). La influencia de la composición del fundido sobre estas propiedades puede entenderse estudiando su estructura (19). El orden de corto y medio alcance en la distribución de los componentes de la red vítrea se ha determinado por métodos físicos directos (Espectroscopía de IR y RMN). El agua incluída en el fundido despolimeriza la estructura a altas temperaturas de la red de alumino-silicato. Pero en fundidos binarios de silicatos alcalinos no afecta a la distribución de los anillos reticulares, mientras que en fundidos con óxido de aluminio en la red vítrea
$4 w t \%$ to 4-5 days for a water content of about 0.7 wt\% (see Figure 11). Therefore, for practical processing purposes, in general the water will facilitate crystallization of the glass-forming melts and glasses essentially through increasing of the crystal number densities and producing products with small grain sizes.

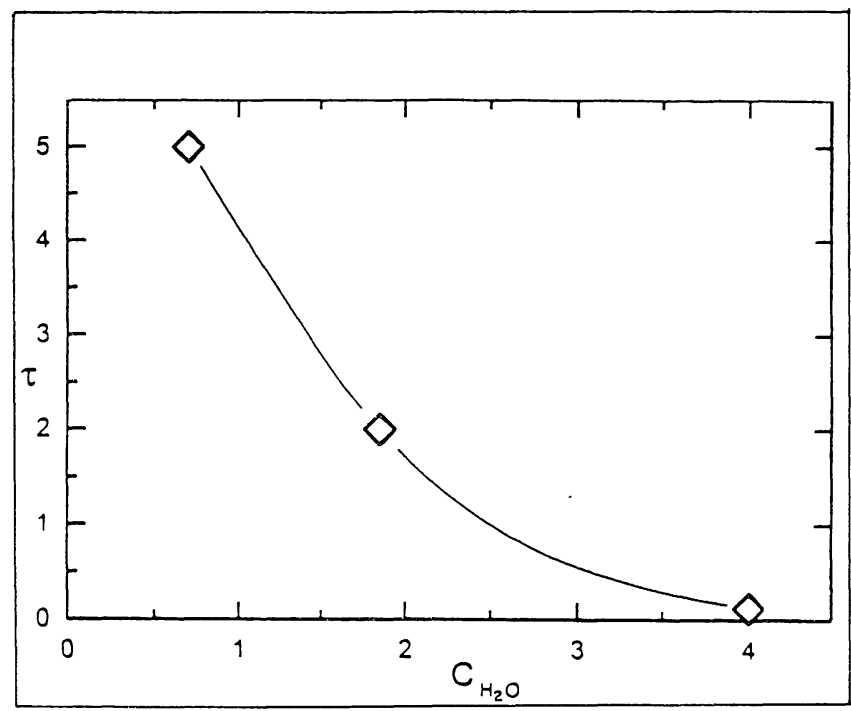

Figura 11.-Dependencia del tiempo de retraso de la nucleación heterogénea de feldespatos alcalinos cristalizados con "semillas" del mismo mineral con grados de subenfriamiento de $\Delta \mathrm{T}=30-80^{\circ} \mathrm{C}$ y con el contenido de agua del granito fundido (Simakin y Chevychelov, 1994) (16).

Figure 11.- Dependence of the delay time (days) of the heterogeneous nucleation of alkali feldspar on the seeds of the same mineral at undercooling $\Delta T=30-80^{\circ} \mathrm{C}$ on the water content in the granite melt (Simakin and Chevychelov, 1994) (16).

\section{CONCLUSION}

Alumino-silicate including granite compositions melts are common in processing of glass-ceramics for construction applications, since they are widely distributed in nature. The kinetic of nucleation and crystallization of crystalline phases from these melts determines the degree of crystallinity and microstructure of final products (Rincón and Romero, 1996)(1). The influence of the melt composition on these properties can be understood while studying the melt structure (19). Local and medium range order in the distribution of network-forming components was determined by direct physical methods (IR spectroscopy, NMR). The water included into the melt by dissolution at high temperatures depolymerizes the alumino-silicate network. But in alkali-silica melts it does not affect the ring distribution while in melts with aluminium oxide reacts with it and transform the four-membered 
transforma los anillos feldespáticos de cuatro miembros (tipo-4) en anillos de seis miembros (tipo6) del tipo de la tridimita. Sin embargo, las velocidades de crecimiento cristalino de vidrios de silicato alcalino aumentan con el contenido en agua de acuerdo con el aumento del transporte por difusión. De manera similar, la destrucción de las unidades de crecimiento del feldespato parcialmente compensan el aumento de la velocidad de transporte de iones por difusión en fundidos de granito hidratados. En ambos casos el agua reduce considerablemente la energía de superficie de la interfase cristal/fundido dando lugar a un aumento de la nucleación homogénea y heterogénea. A consecuencia de la adición de agua el fundido de alumino-silicato cambia la forma de la "nariz" de las curvas TTT de transformación-temperatura- tiempo hacia menores temperaturas y tiempos como han demostrado Zanotto y Galhardi en 1988 (20). Así, la microestructura de los materiales vitrocerámicos producidos a partir de fundidos hidratados puede ser modelada controlando los parámetros cinéticos de los procesos de nucleación y crecimiento cristalino.

\section{AGRADECIMIENTOS}

Los autores agradecen la ayuda financiera de la Academia Rusa de Ciencias y el Dpto. de Relaciones Internacionales del CSIC para la estancia de los Drs. Salova y Simakin en el Laboratorio de Materiales Vitrocerámicos del Instituto E. Torroja, Madrid.

Los autores agradecen la discusión y valiosos comentarios de C. J. R. González Oliver, de la División de Materiales del Centro Atómico de Bariloche, Argentina feldspar rings into tridymite-like six-membered rings. Nevertheless, the growth rates of alkalisilicates glasses increases with water content in accordance with the enhanced diffusion transport. Similarly, the destruction of feldspar growth units partly compensates the increase of diffusion transport rate on hydrous granite melts. In both cases water substantially reduces surface energy of crystal/melt interface resulted in the large homogeneous and heterogeneous nucleation rates increase. As a consequence of the water addition to the alumino-silicate melts shifting of the nose of TTT diagrams to the smaller times and lower temperatures can be demonstrated following Zanotto and Galhardi, 1988 (20). Thus, the microstructure of glass-ceramics produced from hydrous melts can be modeled by controlling the kinetic parameters of thermal process for nucleation and growth of crystallites.

\section{ACKNOWLEDGEMENTS}

Many thanks are due to financial help for a short stage for Drs. Salova and Simakin to Russian Academy of Sciences and Dept. of International Relations CSIC, Spain, at the Glass-Ceramics Lab of the Institute E. Torroja, Madrid.

\section{Authors are very grateful for discussion and} valuable comments from C. J. R. González-Oliver of the Division of Materials, Centro Atómico de Bariloche, Argentina.

\section{BIBLIOGRAFÍA}

(1) Rincón, J.Ma. and Romero, M. Glass- ceramics as building materials Materiales de Construccion, 46 (1996) 91-106.

(2) Swanson, Relation of nucleation and crystal -growth rate to the development of granitic textures, American Mineralogist, 1977,v. 62, p. 966-978.

(3) Stebbins, J.F.: Identification of multiple structural species in silicate glasses by ${ }^{29} \mathrm{Si} \mathrm{NMR}$. Nature 330(1987)465-467

(4) McMillan, P.: Structural studies of silicate glasses and melts - applications and limitations of Raman spectroscopy. Amer. Mineral. 69 (1984)622-644.

(5) Mysen, B.O. and Frantz, J.D.: Structure and properties of alkali silicate melts at magmatic temperatures. Eur.J.Mineral.5(1993)393-407.

(6) Zotov, N. and Keppler, H. The influence of water on the structure of hydrous sodium tetrasilicate glasses. Amer. Mineralogist 83 (1998) p.823-834.

(7) Sykes, D., Marians, J.C., and Burdett J.: Geometric constraints: a refined model for the structure of silica glass. J.Non Cryst. Solids. 1990.

V. 124. P. 1.

(8) Kubicki, J.D. and Sykes, D. Molecular orbital calcutions of vibrations in threemembered alumosilicate rings. Phys.Chem.Miner. 1993.

V. 19. P. 381.

(9) Simakin, A.G., Salova, T.P., Epel'baum, M.B. and Bondarenko, G.V. Influence of water on the middle - range alumosilicate structure, Geokhimia, No 8 (1998)p.861-864 (in Russian).

(10) Zavel'Sky V.O., Salova T:P. The role of sodium in the mechanism of the interaction of water fluid with sodium-silica melt (NMR 'H,

${ }^{23} \mathrm{Na}$ ). Experiments in Geoscience, 1999, vol.8, № 2 (in press). 
(11) Tuttle, O.F. and Bowen, N.L. Origin of granite in the light of experimental studies in the system $\mathrm{NaAlSi}_{3} \mathrm{O}_{8}-\mathrm{KAlSi}_{2} \mathrm{O}_{8}-\mathrm{SiO}_{2}-\mathrm{H}_{2} \mathrm{O}$ .The Geol. Soc. of Amer.Memoir 74, 1958, 153.

(12)Kuznetcov, A.D. and Epel'Baum, M.B.: Eutectic relations in the open systems with perfectly mobile components. M.Nauka, 1985, 109 $\mathrm{P}$ (in Russian).

(13) González-Oliver, C.J.R., Johnson, P.S., and James, P.F. Influence of water on the rates of crystal nucleation and growth in lithia-silica and soda-lime silica glasses. J.Materials Science 14(1979) 1159-1169.

(14) Mungall, J.E., Romanio, C., Dingwell D.B. Multicomponent diffusion in the molten system $\mathrm{K}_{2} \mathrm{O}-\mathrm{Na}_{2} \mathrm{O}-\mathrm{Al}_{2} \mathrm{O}_{3}-\mathrm{SiO}_{2}-\mathrm{H}_{2} \mathrm{O}$. Amer. Mineral. 83(1998)p.685-699.

(15) Simakin, A.G. Kinetic regularities in the growth of magmatic minerals. Petrology, vol.1,N5, 1993, pp.486-491 (Translated from Petrologiya, v.1, $\mathrm{N}^{\circ} 5$,pp. 550-556).

(16) Simakin, A.G. and Chevychelov, V. YU. An experimental study of the crystallization of Fsp from granitic melts with various water content. Geoch. Internat. 10(1995) 114 (translated from Geokhimiya 2(1995)216-238).

(17) P.M. Fenn, The nucleation and growth of alkali feldspars from hydrous melts, The Canadian Mineralogist 15(1977), 135-161

(18) Muncill, G.E. and Lasaga, A.C., Crystal-growth kinetics of plagioclase in igneous systems: Isothermal $\mathrm{H}_{2} \mathrm{O}$ - saturated experiments and extension of a growth model to complex silicate melts. American Mineralogist 73 (1988), 982-992.

(19) Muller, E., Heide, K. and Zanotto, E.D.: Molecular structure and nucleation in silicate glasses. J.Non Cryst.Solids, 155 (1993) 56-66.

(20) Zanotto, E.D. and Galhardi, A. Experimental test of the general theory of transformation kinetics: homogeneous nucleation in a $\mathrm{Na}_{2} \mathrm{O} \cdot 2 \mathrm{CaO} \cdot 3 \mathrm{SiO}_{2}$ glass. J. Non-Crystal. Solids 104 (1988) 73-80. 